\title{
TEMAS WAGNERIANOS USADOS POR EL HUMOR GRÁFICO PARA LA SÁTIRA POLÍTICA EN TORNO AL DESASTRE DEL $98^{*}$
}

\author{
José Ignacio SuÁrez GARcía \\ Universidad de Oviedo
}

Resumen: El humor gráfico usó temas wagnerianos para hacer sátiras políticas centradas en asuntos relacionados con las circunstancias atravesadas por España en torno al Desastre de 1898. Combinó, así, motivos extraídos de una cultura elevada con mecanismos propios de los medios de comunicación de masas escritos. Los ejemplos que explicamos ponen de manifiesto que los argumentos wagnerianos fueron lo suficientemente populares como para poder ser reconocidos fácilmente por el lector-espectador. Su interpretación en clave política, a través de técnicas propias de la parodia, presenta un espesor tropológico e intertextual complejo, que solo es posible descubrir tras un exhaustivo estudio.

Palabras clave: Richard Wagner, recepción en Madrid, humor gráfico, generales españoles, sátira política.

WAGNERIAN TOPICS USED IN GRAPHIC HUMOR AS POLITICAL SATIRE ABOUT THE DISASTER OF 1898

* El presente estudio se enmarca dentro de los proyectos de investigación titulados Microhistoria de la música española contemporánea: ciudades, teatros, repertorios, instituciones y músicos (HAR2015-69931-C3-3-P) y Espacios, géneros y públicos de la música en Madrid, ss. XVII-XX (S2015/ HUM-3483). Quiero agradecer las sabias orientaciones del profesor Sergio Sánchez Collantes al iniciar el presente estudio. 
Abstract: Graphic humour used Wagnerian topics to make political satire focused on affairs related to the circumstances Spain experienced due to the Disaster of 1898 . As such, it combined graphic motifs extracted from high culture with its own techniques for mass media prints. The examples explained show that the Wagnerian arguments were popular enough to be easily recognized by the reader-audience. Its interpretation in a political mode - through its own techniques of parody-presents a complex tropological and intertextual density, which is only possible to discover after exhaustive research.

Keywords: Richard Wagner, reception in Madrid, graphic humor, Spanish Generals, political satire.

Richard Wagner fue en la segunda mitad del siglo XIX una personalidad que en Madrid trascendió ampliamente el plano meramente musical para convertirse en un verdadero personaje mediático. Este hecho explica que el compositor y su obra pudieran convertirse en trasunto de manifestaciones humorísticas de muy diversa naturaleza, que van de la zarzuela paródica a la poesía satírica, pasando por el chiste y la gacetilla periodística. Fuera de estos ámbitos también fue tratado por el humor gráfico, en formatos que usan técnicas y maneras tomadas de la caricatura, como la viñeta suelta, la tira cómica y la página cómica. Su aparición como objeto destinado a hacer reír, en todos estos géneros, redunda en la idea de que su fama traspasó lo puramente artístico para llegar a ser un auténtico fenómeno de masas. Al margen de su lado más lúdico, es decir, de su primera y genérica intención de diversión o entretenimiento, en el humor gráfico existe además un discurso interno, un mensaje que va desde la sátira política a la pulla didáctica. Dicho de otra manera, dentro de esta clase de humor hay espacio para reír y para pensar, para la diversión y la reflexión. En una ocasión anterior, en que expusimos el oportuno marco teórico y epistemológico que sustenta el presente trabajo, se subrayó cómo en este tipo de expresión, tan propio de los medios de comunicación escritos de la época, se puede entrever una crítica al sistema de Wagner, a sus libretos, a los intérpretes de sus obras y a la moda en que llegó a conformarse el wagnerismo en Madrid en los años de cambio del siglo XIX al XX1. No obstante, entonces dejábamos apuntado que, debido a la cantidad de material gráfico encontrado, tenía

${ }^{1}$ SuÁrez García, José Ignacio. «Graphic humour as musical criticism: cartoon and caricature in the first Wagnerian reception in Madrid». Nineteenth-Century Music Criticism. Teresa Cascudo García-Villaraco (ed.). Turnhout, Brepols, 2017, pp. 101-132. 
que quedar para mejor oportunidad el abordar la sátira política basada en asuntos wagnerianos. Hoy, que acometemos esta labor, nos vemos en la obligación nuevamente de acotar nuestro estudio, restringiéndolo a aquellos ejemplos publicados en torno al Desastre colonial de 1898. Y lo hacemos no tanto por un exceso de casos, sino por la complejidad de explicar el abigarrado espesor tropológico e intertextual de las imágenes localizadas y los textos que las acompañan.

Manuel Âlvarez Junco - a quien seguimos en las próximas líneas- ha establecido con nitidez los elementos configuradores del humor gráfico: la adecuada contextualización conceptual y formal, la transgresión significativa del orden normal establecido (lo que le permite convertirse en crítica) y la complicidad del receptor con la propuesta hecha por el artista gráfico $^{2}$. No pretendemos reflexionar ahora sobre estos tres aspectos, pero sí detenernos un instante en el primero, en la convicción de que aclarará el planteamiento metodológico del presente artículo, cuyo objetivo es poner al descubierto las claves interpretativas que permitan al lector actual entender los chistes contenidos en las imágenes que se comentan.

Es de sobra conocido que el humor publicado en los medios de comunicación de masas escritos goza de una vida breve, ya que la necesaria complicidad con el lector se desvanece enseguida. Su consumo diario lo hace perecedero y con el paso del tiempo se vuelve poco efectivo. La razón no es otra que las propias temáticas empleadas, que solo son entendibles por unos destinatarios próximos a lo contado. Además, el cambio de los factores culturales y sociales propios del devenir histórico pueden llegar a hacerlo completamente incomprensible, al desconocer el receptor el desarrollo de la anécdota. Por eso puede afirmarse que el humor suele estar ligado a la contemporaneidad, a la actualidad y lo espontáneo de cada época, tanto como cambian los gustos de la sociedad en la que se desarrolla. La contextualización temporal es, por tanto, un condicionante imperativo cuando el investigador trata manifestaciones históricas, porque sin su adecuada identificación, este humor se torna absolutamente enigmático. Sin esta "puesta en situación» el chiste hoy resulta completamente desprovisto de gracia, debido a la devastadora acción del cambio de coordenadas. Perdido el factor actualidad por el transcurso del tiempo, se produce una profunda merma de vigencia. Es, entonces, un humor especialmente sometido al desgaste temporal ya que,

\footnotetext{
${ }^{2}$ Álvarez Junco, Manuel. El diseño de lo incorrecto. La configuración del humor gráfico. Buenos Aires, La Crujía, 2009, pp. 91-138.
} 
conforme nos alejamos de la situación coyuntural que lo produjo, cada vez se hace menos comprensible, llegando incluso a perder todo significado, al desaparecer los referentes que le daban sentido, los que le hicieron nacer y los que le daban entidad.

Todo lo comentado es tanto o más aplicable al humor gráfico. De hecho, si observamos casos que no pertenecen a nuestra época, lo más probable es que nos resulten ininteligibles y no apreciemos su interés: caricaturas de personajes desconocidos, diálogos relativos a no se sabe qué problemas, símbolos cuyas claves no sabemos, etc. Esta falta de accesibilidad nos resulta desconcertante. Simplemente nos faltan, aquí y ahora, los elementos de contextualización propios de su tiempo y lugar, lo cual nos imposibilita su valoración. Por esta razón, el investigador tiene que identificar a los personajes, debe sacar a la luz las claves del momento social, sus circunstancias, los problemas que preocupaban entonces y la razón última que detonó su aparición. Porque, normalmente, el chiste gráfico es consecuencia de una situación concreta, está provocado por un problema específico, dirigido a un público predeterminado y destinado a un fin preciso. Si no conocemos su contexto, no podemos apreciar su sentido. Esta problemática es especialmente acuciante en la sátira política, donde el instante, el momento sincrónico, suele ser el determinante, resultando de ello una tremenda fugacidad de su asunto cómico. Debido a este comportamiento, el principal objetivo de nuestro desarrollo expositivo es hacer comprensibles los ejemplos, a pesar de que somos plenamente conscientes de lo que afirma Gombrich cuando dice que «no hay modo más seguro de matar un chiste que explicarlo» ${ }^{3}$, una opinión válida para un público cercano, pero que no tiene en cuenta la perspectiva histórica.

En sentido opuesto - y dada la capacidad de la caricatura para sintetizar visualmente cuestiones complejas, como los sucesos políticos- la prensa satírica de la edad contemporánea ha sido fuente inagotable para la reconstrucción de la opinión pública, las mentalidades y los comportamientos. Por eso, a través del humor gráfico se pueden seguir perfectamente los hechos más relevantes de la historia de un país, como ha demostrado la profesora García Quirós para el caso español en los años próximos al 98. El caricaturista se convierte en un periodista que plasma los acontecimientos más destacados del momento y lo hace, como en toda sátira, de manera tendenciosa: no es un informador imparcial, que se dedica a dejar

\footnotetext{
${ }^{3}$ Gombrich, Ernst Hans. Meditaciones sobre un caballo de juguete. Barcelona, Seix Barral, 1968 , p. 47.
} 
constancia de los sucesos, sino auténtico articulista de fondo que señala, al menos, el punto de vista del periódico para el que trabaja, cuando no el personal ${ }^{4}$. En este sentido, aclaramos que las dos revistas en las que hemos hallado ejemplos, Gedeón y Blanco y Negro, ambas estrechamente vinculadas entre sí al compartir varios redactores y colaboradores, son de tendencia conservadora. De ahí su preferencia por atacar a Práxedes Mateo Sagasta y a todo el espectro político situado más a la izquierda de él, lo cual no es óbice para la crítica a Antonio Cánovas o cualquier otro partido o ideología. Refiriéndose exclusivamente a Gedeón, García Quirós ha señalado que «los humoristas mantienen una actitud de independencia ideológica, criticando tanto a liberales como a conservadores, poniendo siempre el interés de la patria por encima de todo» ${ }^{5}$.

Como otros periodos de profundas convulsiones, la etapa finisecular fue especialmente rica en sátira política, ya que la óptica jocosa propiciaba la evasión ansiada por la sociedad española ante la gravedad de los hechos derivados del conflicto colonial. En lo tocante a la basada en temas wagnerianos, su objetivo preferido fueron militares que ostentaron el puesto de capitanes generales en posesiones de ultramar, concretamente Arsenio Martínez Campos (1831-1900), Valeriano Weyler (1838-1930) y Camilo García Polavieja (1838-1914). Cabría decir que la prensa fue la única «instancia de poder» que se permitió desafiar al ejército, la única que se atrevió a acusar a mandos de máxima graduación, con gracia, pero sin contemplaciones. La prodigalidad de este tipo de críticas —dice López Serrano- era «un síntoma más de la pérdida de la confianza de la sociedad española en sus dirigentes y del desgaste de sus valores tradicionales» ${ }^{6}$. Otro aspecto que ha subrayado la historiografía ha sido que el paso por la Capitanía General de Cuba supuso para la mayoría de estos altos cargos castrenses un destacadísimo trampolín y una importante cobertura para su consolidación en el poder, algo que es aplicable en gran medida a los tres casos citados. Resulta complejo sintetizar en unas líneas el trasfondo, más superficial siquiera, de la problemática histórica de los momentos inmediatamente anteriores al tratado por las imágenes que vamos a comentar seguidamente. No obstante, Cayuela Fernández ha explicado magistralmente las relaciones entre el grupo pro-peninsular de La Habana

${ }^{4}$ García Quirós, Rosa María. «Política y caricatura: el desastre colonial español a los ojos de los humoristas gráficos (1895-1898)». Liño, 5 (1985), pp. 115-132, p. 115.

${ }^{5}$ Ibid., p. 131.

${ }^{6}$ López Serrano, Alfredo. El general Polavieja y su actividad política y militar. 2 vols., Madrid, Ministerio de Defensa, 2001, vol. 2, p. 537. 
con un cerrado sector de mandos de la cúpula de las fuerzas armadas españolas, una vinculación que trató de sustentar el estatus colonial y la propia consolidación patrimonial de aquellos poderosos habaneros. Las alianzas entre las élites económicas coloniales y metropolitanas fueron posibles, en gran medida, gracias a la relación entre la oligarquía cubana con el generalato, que trató de preservar férreamente la situación, en detrimento de las libertades del resto de la élite antillana. Durante un tiempo, la política que trataba de mantener el statu quo se combinó, sin embargo, con el intento de atracción de los reformistas, que demandaban cambios en Cuba. No obstante, esta estrategia bipolar acabó de romperse con la línea dura practicada por Francisco Lersundi (1866-1869), que aceleró el desencadenamiento del Grito de Yara y la Guerra de los Diez Años (1868-1878). Firmada la paz de Zanjón (1878), el nombramiento de Capitán General obedeció a los cambios de turno de partido característicos del sistema canovista. La mayoría de los capitanes generales fueron, desde entonces hasta 1895, la representación de un sistema social y político de carácter oligárquico que, a ambos lados del Atlántico, se empeñó en salvaguardar sus intereses, negando implícitamente el proceso de concesión de autonomía a la isla como posible medio de remediar el definitivo enfrentamiento con los partidarios de la independencia. La autonomía llegó tarde y forzadamente en 1897, a destiempo, y por eso apenas tuvo validez, puesto que los insurrectos no aceptaron pacto alguno ni con la Capitanía General, ni con el Gobierno de Madrid7.

En la imagen, publicada a finales de enero de 1896 en la revista satírica Gedeón bajo el título «El regreso de Lohengrin» (Ilustración 1) ${ }^{8}$, se ve al general Arsenio Martínez Campos ataviado como el Caballero del cisne, uno de los roles operísticos que, en ese final de siglo, mejor personificaban la idea de cortés gentileza, en el sentido medieval -y romántico- de la expresión. La caricatura nos sitúa en el momento de llegada del héroe wagneriano, que está a punto de desembarcar para defender a la soñadora Elsa (acto I, escena $3^{a}$ ). En ella se hace una crítica mordaz del regreso, desde Cuba, de Martínez Campos a España y de la actitud trasnochada mostrada por el general en la guerra de independencia cubana. Reabierto el conflicto en febrero de 1895, Martínez Campos fracasó en la misión de pacificar la isla, objetivo que persiguió a través de una política de concilia-

\footnotetext{
${ }^{7}$ Cayuela Fernández, José Gregorio. «Los capitanes generales de Cuba: elites coloniales y elites metropolitanas (1823-1898)». Historia Contemporánea, 13-14 (1996), pp. 197-221.

${ }^{8}$ Sileno (pseudónimo de Villahermosa Borao, Pedro Antonio). «El regreso de Lohengrin». Gedeón, II, 12 (30 de enero de 1896), p. 4.
} 


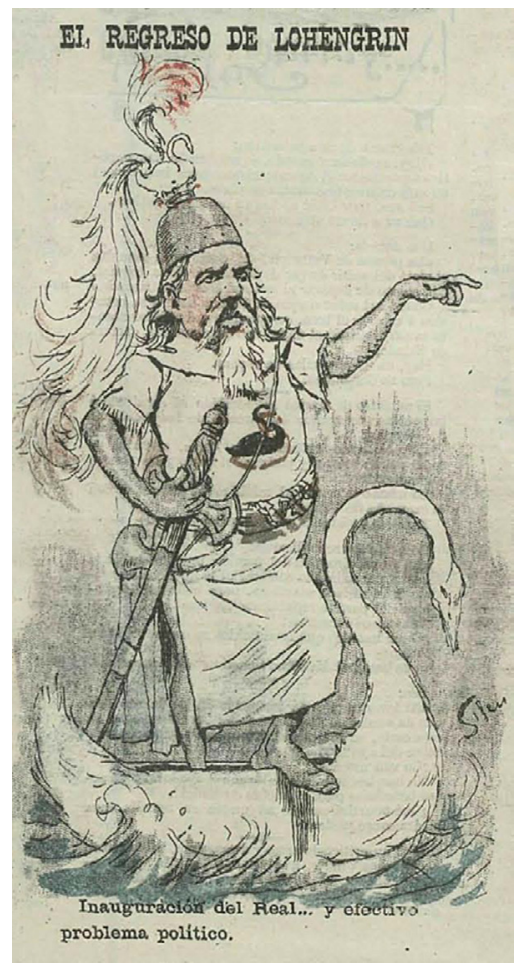

Ilustración 1. «El regreso de Lohengrin», Gedeón. Sileno, 1896.

ción, aun siendo consciente de que las circunstancias aconsejaban aplicar estrategias de represión, reconcentrando familias y aislando poblados, duras medidas que él se vio incapaz de tomar por humanidad. Por eso, tanto en la Península como en el círculo revolucionario cubano de París se le acusó de ser un iluso, de haber pecado de optimismo y de exceso de benevolencia; en una palabra, de haber sido un idealista romántico, una actitud que da sentido al dibujo. De hecho, la ineficacia de su política quedó al descubierto al entrar la caballería mambisa en la provincia de La Habana el 1 de enero de 1896, siendo puesta en estado de alerta la misma capital. A los pocos días se hizo patente la desconfianza hacia el militar español y poco después, el 16 de enero, el gobierno de Cánovas autorizó a Martínez Campos a entregar el mando y a regresar a la Península: era la fórmula eufemística usada para encubrir una destitución?

\footnotetext{
${ }^{9}$ Navarro García, Luis. «La última campaña del general Martínez Campos: Cuba, 1895». Anuario de estudios americanos, 58, 1 (2001), pp. 185-208.
} 
Pedro Antonio Villahermosa Borao (1869-1945), que utilizaba el pseudónimo de Sileno, coloca debajo del grabado una etiqueta que, para el lector de entonces, delimita un tanto la situación: «Inauguración del Real... y efectivo problema político». En su primera parte el texto hace referencia a las extraordinarias circunstancias atravesadas por el teatro de ópera madrileño, pues lo normal era que su temporada comenzara en otoño. Sin embargo, su empresario - Luciano Rodrigo- había suspendido pagos por bancarrota, así que el gobierno rescindió su contrato el 1 de enero de 1896. Tras subasta pública, se hizo con el coliseo el editor de música Benito Zozaya, que tardó tan solo cuatro días en declararse insolvente para ponerlo de nuevo en funcionamiento hasta que, finalmente, otro de los solicitantes del concurso, Manuel González Araco, logró reabrirlo el 26 de enero, con la puesta en escena de Lohengrin, precisamente ${ }^{10}$. La segunda parte usa el doble sentido para referirse a lo que se acaba de comentar y, también, para plantear algo que se puede formular como pregunta: después del fracaso de Martínez Campos, ¿dónde se puede colocar al militar artífice de la restauración borbónica?, ¿qué se puede hacer con un general de su trayectoria? La respuesta a estas preguntas fue nombrarlo presidente del Consejo Supremo de Guerra y Marina, de ahí una estrofa publicada en la misma página de Gedeón, que también menciona a su sucesor en Cuba, el general Valeriano Weyler, que aplicó una política mucho más violenta en la Gran Antilla:

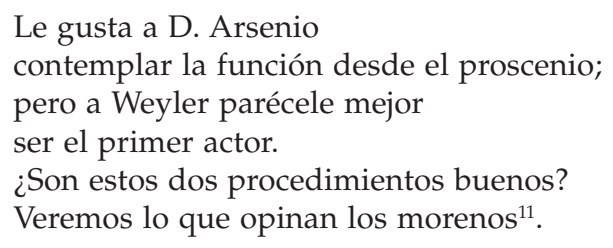

En «Al salir del consejo» (Ilustración 2) ${ }^{12}$, Sileno retrata a algunos miembros del gabinete de gobierno. En primer término aparece Cánovas con un cartapacio en el que se adivina a leer la palabra «presidencia». A su lado, de baja estatura, el ministro de Ultramar, Tomás Castellano. Detrás del presidente está el ministro de la Guerra, el general Marcelo Azcárraga que, con cinta y galones, porta una carta del general Pola-

\footnotetext{
${ }^{10}$ Turina Gómez, Joaquín. Historia del Teatro Real. Madrid, Alianza, 1997, pp. 181-184 y 417.

11 «Moralejas de Gedeón». Gedeón, II, 12 (30 de enero de 1896), p. 4.

12 Sileno (pseudónimo de Villahermosa Borao, Pedro Antonio). «Al salir del Consejo». Gedeón, III, 71 (18 de marzo de 1897), p. 1.
} 
vieja, el cual no contaba con las simpatías de Cánovas. Tras Azcárraga, atravesando el cortinaje, se distingue al ministro de Hacienda, Juan Navarro Reverter. En la parte superior - y fuera de escena- vemos a Gedeón, el protagonista de la revista satírica de idéntico nombre, que está dirigiendo una partitura de Wagner. El chiste reside en que la música del compositor alemán era conceptuada como algo tan difícil de concertar como los intereses encontrados del ministro de Ultramar, el bajito Tomás Castellano, y el de Hacienda, Juan Navarro Reverter. Esta discrepancia venía motivada por la insistente petición de dinero y refuerzos del general Polavieja para sofocar la insurrección filipina a principios de marzo de 1897. Convirtiéndose en el chisme político del momento, el episodio se vio como un recrudecimiento de la mutua antipatía que se profesaban ambos ministros. Ante la negativa de Cánovas a enviar todas las tropas que exigía Polavieja, este presentó su dimisión. A pesar de que ya estaban extendidos los decretos que, respectivamente, admitían la renuncia y nombraban sucesor de Polavieja, el encubierto cese no fue aceptado por la reina regente, María Cristina de Habsburgo-Lorena, lo que ocasionó el desaire de Cánovas, de cuya cartera - en la imagen- se caen los mencionados decretos. La imposición del criterio de la regente supuso un duro revés para Cánovas y a punto estuvo de provocar una crisis de gobierno ${ }^{13}$, de ahí la leyenda que acompaña al grabado: «manos blancas no ofenden». La expresión alude, no tanto a la novela homónima calderoniana, sino más bien a la célebre frase pronunciada por el ministro Calomarde tras un recio bofetón que le había propinado Carlota de Borbón a finales de 1832. Entonces, con Fernando VII agonizante, aquella mujer había logrado que se detuviera el intento de Calomarde de restituir la ley sálica; en 1897 María Cristina conseguía mantener en su puesto a uno de sus generales favoritos en contra de la opinión de Cánovas: toda una bofetada para el presidente. Gedeón dirigiendo detrás del atril también podría hacer referencia a que la controvertida obra de Wagner era la música incidental idónea para una situación tan polémica e, incluso, haciendo un juego de palabras con el título del grabado - «Al salir del consejo»- podría aludir a un fragmento que acababa de obtener gran éxito en una sesión de la Sociedad de Conciertos de Madrid: la entrada de los dioses en el Walhalla.

${ }^{13}$ Soldevilla, Fernando. El Año político (1897). Gerona, Tip. del Hospicio Provincial, 1898, pp. 85-89. 


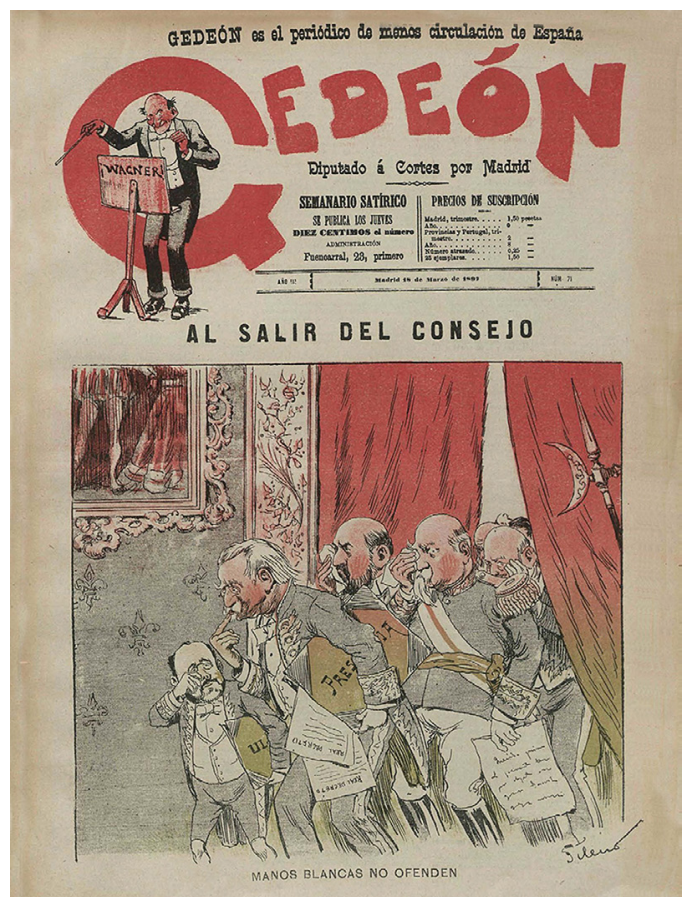

Ilustración 2. «Al salir del Consejo», Gedeón. Sileno, 1897.

El motivo que da lugar a la publicación de «Género chico. El buque fantasma» (Ilustración 3) ${ }^{14}$ fue la destitución de Valeriano Weyler como Capitán General de Cuba, así como su subsiguiente regreso a la península en noviembre de 1897, vía Puerto Rico. Fue un accidentado viaje que, a causa de una avería, le obligó a una breve escala en Cibara (Cuba), lo que dio ocasión a que se desatasen los rumores sobre una supuesta intención de sublevación ${ }^{15}$. En el dibujo de Ramón Cilla (1859-1937) vemos que, frente a las candilejas de un pequeño teatro dedicado al género chico, aparece Weyler capitaneando un fantasmagórico barco: la conversión de la ópera de Wagner, de gran duración, en una obra en un solo acto, es el primer elemento paródico. Desde una orilla rocosa, a modo de sirenas que tratan de seducir y cautivar al marinero, hay tres personajes cuyos gorros delatan su filiación política o geográfica. Son, de izquierda a de-

\footnotetext{
${ }^{14}$ Cilla, Ramón y Royo Villanova, Luis. «El Buque fantasma». Blanco y Negro, VII, 343 (27 de noviembre de 1897), p. 10.

${ }^{15}$ Diego, Emilio de. Weyler, de la leyenda a la historia. Madrid, Fundación Cánovas del Castillo, 1998, pp. 228-233.
} 


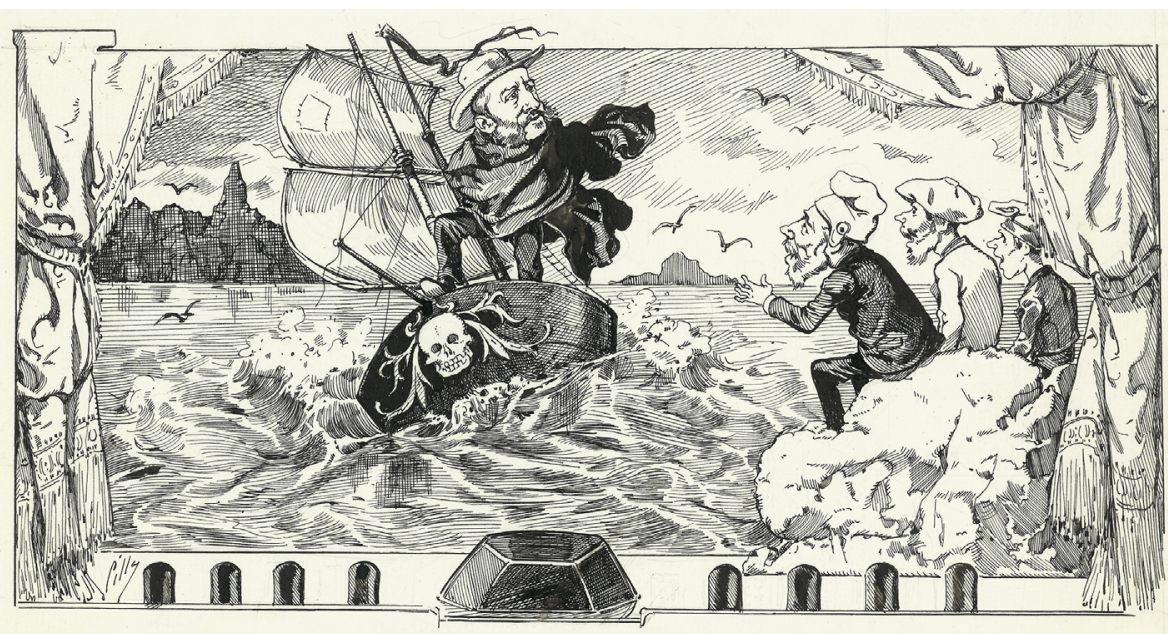

Ilustración 3. «Género chico. El buque fantasma», Museo ABC de Dibujo e Ilustración. Ramón Cilla, 1897.

recha: un republicano (gorro frigio con escarapela), un carlista (boina) y un catalán (barretina). Los tres representan a sendas delegaciones que se encargaron de dar la bienvenida al general a su vuelta de Cuba, un viaje que llevó a Weyler primero a La Coruña donde, con el propósito de atraerle a sus respectivas filas, fue visitado, entre otras, por comisiones de republicanos y carlistas. Weyler se dirigió luego a Barcelona, donde fue muy bien recibido por los industriales de Cataluña, los cuales veían peligrar sus intereses económicos en Cuba tras el cese forzado de Weyler y la concesión a la isla de autonomía arancelaria ${ }^{16}$. Finalmente, el general depuesto se trasladó a su ciudad natal, Palma de Mallorca, donde carlistas y republicanos propusieron que una plaza llevara su nombre ${ }^{17}$.

La actitud desafiante y brabucona de Weyler, casi chulesca, ante el cese impuesto por el gobierno presidido por Sagasta ${ }^{18}$ encaja bien con el apelativo del buque: «fantasma». Como en el libreto wagneriano, el ficticio telón de fondo está ocupado en buena parte por una costa escarpada conformada por acantilados ${ }^{19}$. Inmediatamente debajo de la ilustración

\footnotetext{
${ }^{16}$ Soldevilla, F. El Año político (1897)..., pp. 382-385.

17 «Telegramas (recibidos a última hora). Esperando a Weyler». El Siglo Futuro, XXIII, nº 6840 (25 de noviembre de 1897), p. 3.

${ }^{18}$ Soldevilla, F. El Año político (1897)..., pp. 348-353.

${ }^{19}$ WAGNer, Richard. El Holandés errante. Libreto (alemán - español), presentación y comentario. Buenos Aires, Javier Vergara, 1992, p. 13.
} 
de Cilla un texto del redactor jefe de Blanco y Negro, Luis Royo Villanova (1866-1900), comenta y aclara la acción; dice así (procuramos seguir el diseño del original publicado en la revista):

\title{
GÉNERO CHICO \\ EL BUQUE FANTASMA
}

\author{
ARREGLO WEYLERIANO DE LA ÓPERA WAGNERIANA. CONVIENE ADVERTIR AL \\ LECTOR OUE EL ARREGLO ES MALO. \\ PERO COMO DICE PRIMO DE RIVERA POR EL CABLE, «MÁS VALE UN MAL ARREGLO \\ QUE UN BUEN PLEITO».
}

(La escena representa un puerto español cualquiera: lo mismo da el puerto de Pajares que el puerto de Arrebatacapas. Al levantarse el telón aparece en el fondo la misteriosa silueta del barco fantasma tal como lo describe el poema: negro el casco, negra la arboladura, de color de sangre las hinchadas velas que bombea el viento)

\section{EL CAPITÁN}

¿Conocéis la historia del Holandés errante? Pues esa es la mía. Azotado por todos los vientos y perseguido por todas las tempestades, mi barco recorre los mares de España errabundo y perdido, como el barco del Holandés recorría los mares de Noruega. Dos años hace que pesa en los mares sobre mí la maldición que pesa en la tierra sobre el judío de los siete clavos. Arribo a las playas, y las playas me escupen una tras otra; mi brújula, atacada de locura, jamás señala al Norte; huye de mí cuanto persigo; mi barco, jamás anclado, es el eterno juguete de las olas.

(Atraídos por la voz del capitán, van saliendo al escenario los coros de ambos sexos, el carlista y el romerista; doncellas rubias con manojos de oloroso romero recién cortado, y campesinos robustos con jugosas setas recién arrancadas del pie de robles tradicionales, cuanto más tradicionales mejor).

\section{SIGUE EL CAPITÁN}

Sobre mi barco errante pesa há dos años la maldición de todas las estrellas: la solitaria y las demás. Mi barco errante ha corrido sin rumbo ni derrotero el mar Caribe y el golfo de México. Desde el cabo de San Antonio a la punta de Maisí, jamás pude topar con un barco filibustero ni con un filibustero sin barco. Loco y desatentado llegué al puerto de Mariel y al de La Habana, recorrí el río Cauto y di la vuelta a la Isla de Pinos, sin encontrar jamás alma viviente; conmigo iban la soledad, la devastación y la ruina. Tomé rumbo hacia Europa, y los hados me hicieron retroceder a Gibara; salí otra vez, y hube de tocar en Puerto Rico; errante y perdido siempre, llegué a la Coruña, y el viento de la fatalidad me empujó de nuevo, haciéndome dar vuelta a la Península como antes di la vuelta a la Gran Antilla: errante, perdido y fugitivo siempre, lo mismo en el Golfo de México que en el Océano, ya en el Estrecho de Gibraltar, ya en el suave Mediterráneo, que solo para mí se encrespa.

\section{LAS DONCELLAS}

¡Oh, desdichado! ¿Y cuál es el talismán que puede librarte del encantamiento?

\section{LOS CAMPESINOS}

Dinos un remedio. Prontos estamos a buscarlo.

\section{EL CAPITÁN}

¿No conocéis la historia del Holandés errante? Pues esa es la mía. En vano espero un corazón fiel. Solo eso podría dar fin a mis tormentos.

\section{LOS CAMPESINOS}

Un corazón, jah! ése no le hay entre nosotros; aquí te traemos las mejores setas del bosque. Acéptalas, y acaso con eso te baste. Las hay de todas clases: venenosas y hojalateras, es decir, conservadas en lata.

\section{EL CAPITÁN}

Gracias, gracias; pero no es eso lo que busco; necesito un corazón fiel: ya sabéis la historia del Holandés errante.

\section{LAS DONCELLAS}

¿Un corazón fiel? ¡Ah! miradlo, capitán; aquí está la doncella antequerana, la rubia revoltosa de nacarados dientes...

\section{EL CAPITÁN}

La conozco; de doncella ya no tiene nada; de rubia le va quedando poco...

(Cuadro final. El viento ruge, el oleaje aumenta, vira en redondo el buque fantasma alejándose hacia Palma de Mallorca, y la doncella antequerana sepúltase en las aguas del mar)

CONSTERNACIÓN LENTA Y TELÓN RÁPIDO 
Con el propósito de aclarar el sentido para el lector actual, seguidamente se comentan algunas cuestiones procurando seguir la estructura del texto arriba reproducido. Las palabras del encabezamiento, El buque fantasma, provienen de la traducción española de Le Vaisseau fantôme, título de un boceto en prosa realizado por Wagner en francés sobre el asunto de El holandés errante, el cual fue redactado durante su primera estancia en París (1839-1842). Wagner vendió el borrador al director de la Grand Opéra de París, Leon Pillet quien, sin embargo, lo apartó del proyecto, dejándolo en manos del compositor Louis Dietsch y los libretistas Paul Foucher y Bénédicte Henry Revoil, que añadieron un título alternativo ${ }^{20}$ : Le Vaisseau fantôme ou le Maudit des mers. De entonces proviene el nombre con que erróneamente es citada la ópera de Wagner en ocasiones y que, en realidad, fue el más utilizado en las representaciones madrileñas de la época. No obstante, cuando Wagner compuso su propia obra mantuvo el núcleo argumental originario: el holandés errante está perseguido por una maldición que le condena a navegar sin reposo, y solo cada siete años tiene la posibilidad de bajar a tierra en busca del amor puro de una mujer completamente fiel que lo salve, con su propia muerte; es el tema de la redención a través del amor, una de las constantes de la obra wagneriana. Esta mujer es Senta, una joven noruega que, tras jurar lealtad al holandés hasta la muerte, se suicida arrojándose al mar como forma de asegurarse que podrá cumplir su promesa; entonces, los espíritus de Senta y El Holandés ascienden al cielo, como símbolo de que por fin el marinero ha logrado librase de su maldición.

Inmediatamente después del título, Luis Royo advierte que su remedo sobre el drama wagneriano es malo pero, citando a Fernando Primo de Rivera, añade que «más vale un mal arreglo que un buen pleito». La alusión a Primo de Rivera se relaciona con el acuerdo de paz alcanzado entre este general y los cabecillas de la insurrección filipina, el pacto de Biak-na-Bató que, rubricado a los pocos días, fue considerado aceptable casi unánimemente, a pesar de que los jefes de la revuelta pidieron que no se les impusiera castigo alguno y exigieron que el gobierno español facilitara los fondos y la escolta necesaria para que pudieran abandonar el archipiélago ${ }^{21}$. La introductoria acotación de escena, que sigue, remite al acto primero de la ópera wagneriana, y a ella también alude el color negro del casco del barco y sus mástiles. También el rojo sangre del ve-

\footnotetext{
${ }^{20}$ Bauer, Hans Joachim. Guía de Wagner. 2 vols., Madrid, Alianza, 1996, vol. 2, p. 747.

${ }^{21}$ «La pacificación de Filipinas». La Época, XLIX, n 17049 (21 de noviembre de 1897), pp. 1-2.
} 
lamen ${ }^{22}$ que, sin embargo, tiene para el lector coetáneo otra connotación evidente: la fama de sanguinario atribuida a Weyler, que fue exagerada y manipulada por la prensa norteamericana; Weyler era «la hiena mallorquina», el «tigre de la manigua» o, simplemente, «el carnicero» ${ }^{23}$.

El monólogo del capitán, que al igual que el holandés viste negro traje español, parodia toda la escena segunda del libreto wagneriano. En la narración de la maldición, los siete años originales se sustituyen aquí por los dos que lleva Weyler al mando de la isla de Cuba, la cual ha recorrido de punta a punta en busca de filibusteros, desde su extremo occidental (cabo de San Antonio) al oriental (Punta de Maisí). Weyler, que invariablemente se mostró partidario de llevar a cabo una política enérgicamente agresiva contra el bandolerismo ${ }^{24}$, se propuso como objetivo limpiar de filibusteros las provincias occidentales de $\mathrm{Cuba}^{25}$. Sin embargo, la realidad fue que se sintió profundamente frustrado ante la impunidad con que quedaron casi siempre los actos perpetrados por las expediciones marítimas, que partían frecuentemente de suelo norteamericano. Si en el libreto wagneriano el holandés busca sin éxito librarse de su maldición retando a los barcos piratas para lograr su propia muerte ${ }^{26}$, otro tanto se puede decir de la poca fortuna de Weyler en este terreno, pues las escasas capturas de filibusteros concluyeron casi siempre con el indulto de los apresados, a causa de las presiones estadounidenses ${ }^{27}$.

La sátira contra Weyler se agudiza cuando se recuerda que en sus excursiones por Cuba no encontró «jamás alma viviente», un mordaz ataque a su costumbre de hacer expediciones con contingentes de soldados tan numerosos que ninguna partida de rebeldes se atrevía a salirle al paso, algo que fue muy criticado por sus adversarios en España ${ }^{28}$. Con la muerte de su principal valedor, Antonio Cánovas, asesinado en agosto de 1897, Weyler perdió casi su único apoyo real y efectivo dentro del Consejo de Ministros $^{29}$. Asimismo, y tras el deceso, fue destituido de inmediato por

\footnotetext{
${ }^{22}$ Wagner, R. El Holandés errante..., p. 25.

${ }^{23}$ Piñeiro-Otero, Teresa. «Héroes, filibusteros y villanos. Representaciones y mitos de la Guerra de Cuba en la prensa gallega del momento (1895-1898)». Historia y Comunicación Social, 16 (2011), pp. 111-130.

${ }^{24}$ Soldevilla, Fernando. El Año político (1895). Madrid, Imprenta de Enrique Fernández de Rojas, 1896, p. 306.

${ }^{25}$ Ibid., p. 50.

${ }^{26}$ Wagner, R. El Holandés errante..., p. 29.

${ }^{27}$ Soldevilla, F. El Año político (1896)..., pp. 178-190.

${ }^{28}$ Soldevilla, F. El Año político (1897)..., p. 37.

${ }^{29}$ Ibid., p. 60.
} 
el nuevo presidente, Práxedes Mateo Sagasta, entre otras razones porque este siempre había condenado la estrategia defendida por Weyler para la pacificación de la isla, aquella que respondía al lema de «a la guerra con la guerra ${ }^{30}$. La llegada del partido liberal al gobierno supuso un giro en la forma de afrontar el problema cubano: Sagasta concedió enseguida la autonomía a la isla y, con ella, se cedieron las competencias arancelarias a los cubanos, es decir, la imposición de las tasas aduaneras quedó en manos del gobierno insular ${ }^{31}$. En la práctica, esta medida supuso que se abandonaba la tradicional y férrea política proteccionista en favor de otra liberal, que mermó seriamente la capacidad de competitividad de la industria catalana, dejando el comercio de las Antillas en manos de los Estados Unidos. Una de las voces más críticas ante esta medida fue Weyler, que se convirtió en verdadero paladín de la causa proteccionista, lo cual explica las simpatías de los empresarios catalanes y la presencia de un personaje con la típica barretina en el grabado. De hecho, la asociación que agrupaba a los fabricantes más destacados de Cataluña, Fomento del Trabajo Nacional, fue la entidad que más contribuyó a dar brillantez a la llegada de Weyler a la Ciudad Condal organizando, además, una visita a su sede en la que el general volvió a insistir en la necesidad de mantener una política proteccionista en $\mathrm{Cuba}^{32}$.

En el transcurso del soliloquio del capitán (Weyler) salen al escenario coros de ambos sexos, expresión usada en la época para referirse a las dos masas corales que se suelen emplear en los espectáculos de teatro lírico, tanto ópera como zarzuela. Esta división se corresponde también con la usada por Wagner en El holandés errante, donde aparecen un coro femenino, de jóvenes noruegas, y un coro masculino, en este caso subdividido en dos: marineros noruegos y tripulación del holandés. En la parodia de Royo, el coro masculino se convierte en conjunto de carlistas compuesto de campesinos exageradamente tradicionalistas. Recordamos, a este respecto, que el carlismo tuvo escasa repercusión en las grandes ciudades, siendo un movimiento predominantemente rural. El atractivo de Weyler para los carlistas provino - lo mismo que para los republicanos- de cierta desafección mostrada por el militar hacia la reina regente María Cristina, patente sobre todo en momentos en que el general estaba obligado a hacer manifestaciones patrióticas en público, una tibieza que

\footnotetext{
${ }^{30}$ Diego, E. Weyler..., pp. 189-194.

${ }^{31}$ Soldevilla, F. El Año político (1897)..., pp. 390-393.

32 «Llegada del general Weyler». La Vanguardia, XXVII, n 5230 (24 de noviembre de 1897),
} pp. 1-2. 
el carlismo interpretó como rechazo a la línea dinástica de Alfonso XIII $\mathrm{y}$, por consiguiente, un gesto hacia sus intereses. Es más, la prensa norteamericana se había encargado de propagar el bulo de que, si Weyler era sustituido en Cuba, usaría su influencia en el ejército para crear perturbaciones y apoyar la causa carlista ${ }^{33}$, una maniobra estadounidense para poner a la opinión pública en contra de él. De hecho, un polémico brindis realizado por Weyler en Palma de Mallorca, la ausencia total de «vivas» a los reyes en todas sus recepciones desde que había vuelto a la Península, las adulaciones que le habían prodigado republicanos y carlistas y, finalmente, su tardanza para dar explicaciones presentándose en Palacio, dispararon las alarmas ${ }^{34}$. Estas son algunas de las causas por las que los carlistas llevaban meses adulando públicamente a Weyler ${ }^{35}$, hasta tal punto que, con la pérdida de las colonias en 1898, sopesaron un levantamiento insurreccional, que no llegó a producirse, precisamente, debido a la defección del general mallorquín ${ }^{36}$.

El coro femenino está conformado por «doncellas rubias con manojos de oloroso romero recién cortado», referencia tanto a la obra wagneriana como al nuevo Partido Romerista, una facción dirigida por Francisco Romero Robledo, constituida en noviembre de 1897, que acabó por escindirse del Partido Conservador, el cual, tras la muerte de Cánovas, se vio envuelto en una lucha por el liderazgo de la que salió finalmente reforzado Francisco Silvela. Famoso por su rizada melena rubia y su sonrisa afectada de grandes dientes, Romero Robledo era conocido en los círculos políticos como «el pollo de Antequera», debido a su aspecto de galán y a su lugar de origen, la citada villa malagueña. Royo equipara la fidelidad de la protagonista femenina de la ópera wagneriana, Senta, con la lealtad de Romero Robledo hacia el general mallorquín, de ahí que transforme el apodo del político y este se convierta en la fiel «doncella antequerana, la rubia revoltosa de nacarados dientes». Romero Robledo, que trató de atraer a Weyler a las filas de su naciente partido ${ }^{37}$, se mostró siempre firme valedor de la gestión del general en la isla, porque ambos rechazaban rotundamente la autonomía cubana. Esta era la mejor forma de blindar los intereses económicos de la oligarquía burguesa pro-peninsular,

\footnotetext{
${ }^{33}$ Soldevilla, F. El Año político (1897)..., p. 353.

${ }^{34}$ Ibid., p. 423.

${ }^{35}$ Ibid., p. 365.

${ }^{36}$ González CAlleja, Eduardo. La razón de la fuerza: orden público, subversión y violencia política en la España de la Restauración (1875-1917). Madrid, CSIC, 1998, p. 191.

${ }^{37}$ Soldevilla, F. El Año político (1897)..., pp. 377-378.
} 
que apoyó en repetidas ocasiones al militar hasta convertirlo en su ídolo. En este sentido, las simpatías del político hacia Weyler se relacionan con el hecho de que el militar garantizaba la protección de los bienes de la familia política de Robledo Romero en la Gran Antilla: los Zulueta ${ }^{38}$. No es de extrañar, por tanto, que en el momento en que la reina regente llamó a consultas para formar nuevo gobierno tras el asesinato de Cánovas, Romero Robledo se manifestó en contra del relevo de Weyler ${ }^{39}$. Por su parte, el mallorquín expresó públicamente su repulsa hacia el adversario de Romero Robledo, Silvela, a quien Weyler consideraba un «disolvente sin programa ni ideas ${ }^{40}$. Mezclando nueva y habilidosamente el libreto wagneriano y la actualidad política, Royo caricaturiza la caída de Romero Robledo dentro de su antiguo partido en la última acotación de escena: «la doncella antequerana sepúltase en las aguas del mar».

El 25 de enero de 1899 Gedeón publicó «Escena de la Walkyria. Canción de los primaveras» (Ilustración 4$)^{41}$. Allí aparecen, en actitud amorosa, un travestido Francisco Silvela - jefe del Partido Conservador- y el general Camilo García de Polavieja, con su característico bigote. En el texto que acompaña al grabado sus nombres se transforman, respectivamente, en Silvelinda y Camelundo, es decir, el remedo de la traducción castellana de la pareja protagonista de la ópera wagneriana: Siglinda y Sigmundo. Otros elementos, cada uno con su correspondiente leyenda - anotada a continuación entre paréntesis - remiten tanto al final del acto primero de La Valquiria como al contexto político coetáneo: una espada clavada en un árbol (florentina), el cuerno (regeneración) y los efluvios que emanan de la olla (presupuestos). Asimismo, se distinguen un pliego, que porta Polavieja con la palabra "manifiesto», y la luna que, tras una puerta, asiste al encuentro de los amantes.

El asunto principal de la imagen es satirizar el pacto entre ambos políticos, un acuerdo que, producido a principios de enero de 1899, posibilitó, en última instancia, que Silvela llegara a ocupar la presidencia del Consejo de Ministros a principios de marzo ${ }^{42}$. La alianza llegó en un momento de profunda crisis, provocada, sobre todo, por la inevitable asunción de la

\footnotetext{
${ }^{38}$ Véase Apaolaza Ávila, Urko. «Un análisis sobre la historiografía en torno al alavés Julián de Zulueta y Amondo». Sancho el Sabio, 18 (2003), pp. 121-140.

${ }^{39}$ Soldevilla, F. El Año político (1897)..., pp. 336-337.

40 «Declaraciones de Weyler». La Vanguardia, XXVII, n 5230 (24 de noviembre de 1897), p. 6.

${ }^{41}$ Sileno (pseudónimo de Villahermosa Borao, Pedro Antonio). «Escena de la Walkyria. Canción de los primaveras». Gedeón, V, 166 (25 de enero de 1899), p. 1.

42 Véase López Serrano, A. El general Polavieja..., vol. 2, pp. 469-522.
} 


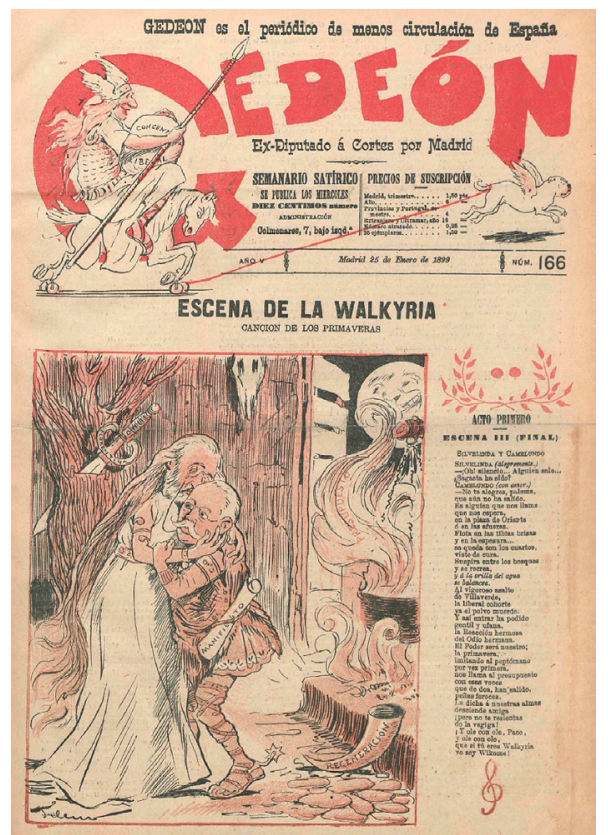

Ilustración 4. «Escena de la Walkyria», Gedeón. Sileno, 1899.

derrota en el conflicto bélico con Estados Unidos, un descalabro que supuso el desmantelamiento definitivo del imperio colonial español, escenificado con la firma del tratado de París en diciembre del año anterior. España capituló con él ante todas las exigencias del vencedor, incluida la cesión a posteriori de Filipinas, puesto que este extremo no se había contemplado en el preliminar arreglo de paz conocido como el Protocolo de Washington. Esta circunstancia hizo que Sagasta se viera en la necesidad de que las Cortes tuvieran que ratificar, por separado, la cesión del archipiélago, pues el parlamento había quedado suspendido desde el último septiembre por real decreto. Reabiertas las cámaras el 20 de febrero, el escasísimo margen con que el gabinete liberal logró sacar adelante el proyecto de ley de cesión de las islas, tan solo dos votos, puso al descubierto que la gobernabilidad era inviable, de manera que Sagasta presentó su dimisión, ocasión que aprovechó Silvela para postularse como nuevo presidente ${ }^{43}$.

El consorcio entre Silvela y Polavieja, que sorprendió a muchos porque poco antes ambos habían manifestado desavenencias notables, es inter-

\footnotetext{
${ }^{43}$ Soldevilla, Fernando. El Año político (1899). Madrid, Imprenta y fotograbado de Enrique Rojas, 1900, pp. 1-85.
} 
pretado por Sileno a través de la parodia del final del acto primero de $\mathrm{La}$ Valquiria, en el cual Siglinda (Silvelinda) y Sigmundo (Camelundo) se declaran su amor en una tibia noche de primavera. El texto que encabeza la ilustración de Sileno sitúa la acción en un momento concreto, la «Canción de la primavera» de Sigmundo, de ahí el subtítulo del dibujo. No obstante, Sileno se permite alguna licencia, pues en ese preciso momento las acotaciones del libreto operístico señalan que solo quedan unas brasas en el fogón, cuando aquí el hogar está avivado por un fuego que está cocinando los inminentes presupuestos que deben ser aprobados en el parlamento, cuyo olor $\mathrm{u}$ aroma provoca, precisamente, la unión de ambos dirigentes.

Bajo el fuego aparece otro símbolo, el cuerno, que representa tanto aquel que, relleno de bebida regeneradora —el hidromiel — comparten los amantes wagnerianos en el drama, como la política que los dos líderes pretendieron aplicar para salvar al país tras el desastre colonial. Un distintivo de Camelundo es, en este sentido, el pliego que porta, que recoge un manifiesto regeneracionista del general. En este texto, Polavieja propuso realizar una verdadera reconstrucción nacional a través de una honda reforma que restaurara la endeudada hacienda pública, eliminara el caciquismo, llevara a cabo una amplia descentralización administrativa y acometiera la reforma del ejército ${ }^{44}$. Al lado de valores nuevos — como la educación útil, el espíritu de trabajo o la eficacia económica- Polavieja apeló en su escrito a otros mucho más tradicionales, mostrándose como un católico practicante de firmes convicciones que proponía respetar a ultranza el Concordato con la Santa Sede (1851), por el cual — recordamos - el Estado se comprometía a mantener el culto y a sus ministros. El manifiesto del "general cristiano", como se le nombró con sorna, pasó casi inadvertido al principio. Sin embargo, poco después de hacerse pública la coalición de fuerzas entre el Partido Conservador y los elementos aportados por Polavieja ${ }^{45}$, el discurso-programa presentado por Silvela puso a las claras que este había aceptado todas las imposiciones del militar, incluso aquellas que levantaban suspicacias, como la cuestión religiosa o el polémico plan regionalista ${ }^{46}$. Para más inri, nada más anunciarse el pacto Polavieja recalcó que no formaba parte del Partido Conservador y que no estaba sujeto a su disciplina, una independencia que, a la larga, causó muchos problemas al futuro gobierno de Silvela. Reflejando una mentalidad machista típicamente decimonónica, esta es la

\footnotetext{
${ }^{44}$ «Las Cortes. Congreso. Del general Polavieja». Heraldo de Madrid (10 de septiembre de 1898), pp. 1-2.

45 «Esperanzas». El Imparcial, XXXIII, n 11389 (5 de enero de 1899), p. 1.

${ }^{46}$ Soldevilla, F. El Año político (1899)..., pp. 6-13.
} 
razón principal por la que Sileno presenta a Silvela como la protagonista femenina y al militar como el hombre, algo que fue glosado jocosamente por varios medios de comunicación. El general Polavieja -leemos en la prensa republicana- «declara que si aquí va a haber matrimonio el varón es él» ${ }^{47}$. A pesar de la visión mayoritaria de sus coetáneos, lo cierto es que los historiadores actuales no dudan en considerar a Silvela como la figura realmente hábil, al ser capaz de atraer al general y capitalizar su enorme prestigio, pues Polavieja arrastraba consigo a una amplia masa social que prestaba su apoyo a la empresa regeneradora ${ }^{48}$.

En la puesta en escena de la obra wagneriana se debe percibir con nitidez la empuñadura de una espada, Nothung («la necesaria»), clavada en un fresno que ocupa la parte central del escenario, que es una cabaña. Siglinda confiesa que se verá irremediablemente atraída por aquel hombre que sea capaz de desenclavar el arma, que en el grabado de Sileno se convierte en "Florentina», sustantivo que alude al apodo de Silvela, pues el político era conocido como el «Caballero de la daga de Florencia», debido a su fama de gran orador, de palabra fluida e incisiva. La transformación de Nothung en Florentina es un guiño de Sileno al rasgo distintivo de Silvela, aunque, sin embargo, no estamos del todo seguros de su preciso significado. En una primera interpretación cabe pensar que, al estar inserta en el árbol, la espada está inmovilizada y, por consiguiente, se cuestionan las dotes persuasivas de Silvela en su negociación con el general. Conforme a ello, la prensa satírica anticlerical recalcó que Silvela no había estado muy lúcido en esa ocasión. También concuerda con la visión de Gedeón en un poema publicado en el mismo número, cuando califica al político conservador como «Dagarrota ${ }^{49}$. Otra posibilidad, quizás menos plausible, es que Sileno entendiera que la perspicacia de Silvela era «necesaria» para alcanzar el gobierno y acometer las reformas y, en este sentido, solo el héroe Camelundo habría sido capaz de despertar su oratoria.

La poesía que acompaña al grabado precisa algo más el tiempo dramático y sitúa la acción en el instante inmediatamente previo la tonada de Segismundo, momento en que Siglinda, vestida con traje blanco, se siente sobresaltada porque la puerta del fondo de la cabaña se abre bruscamente, preguntando seguidamente quién ha salido o entrado. Abierta por completo la puerta, la plateada luz de la luna de una hermosa y apacible noche primaveral ilumina a la pareja, que se contempla extasiada. Entonces Sigmundo,

\footnotetext{
47 «Un hombre». El Nuevo País, II, nº 150 (15 de enero de 1899), p. 1.

${ }^{48}$ López Serrano, A. El general Polavieja..., vol. 2, pp. 487-494.

${ }^{49}$ «Los inmortales de Gedeón. Don Luis de Góngora». Gedeón, V, 166 (25 de enero de 1899), p. 2.
} 
con calor y ternura, le contesta: «nadie se ha ido ${ }^{50}$. El anónimo autor del poema publicado en Gedeón parafrasea y parodia la versión rítmica española del libreto wagneriano, realizada conjuntamente por Juan José Cadenas y el director de escena del Teatro Real, Luis París. Transcribimos a continuación ambos textos, tanto para facilitar la lectura del primero (Gedeón), como para poder hacer la comparación con el segundo (libreto en castellano).

SILVELINDA (alegremente)

¡¡Oh! Silencio... Alguien sale...

¿Sagasta ha sido?

CAmelundo (con amor)

-No te alegres, paloma,

que aún no ha salido.

Es alguien que nos llama

que nos espera,

en la plaza de Oriente

o en las afueras.

Flota en las tibias brisas

y en la espesura...

se queda con los cuartos,

viste de cura.

Suspira entre los bosques

y se recrea

y a la orilla del agua

se balancea.

$\mathrm{Al}$ vigoroso asalto

de Villaverde,

la liberal cohorte

ya el polvo muerde.

Y así entrar ha podido

gentil y ufana

la Reacción hermosa

del Odio hermana.

El Poder será nuestro; la primavera imitando al peptómano por vez primera

nos llama al presupuesto

con esas voces

que de dos, han salido,

peñas feroces.

La dicha a nuestras almas

desciende amiga

¡pero no te resientas

de la vejiga!

¡Y ole con ole, Paco!

y ole con ole,

que si tú eres Walkyria

yo soy Wikome.

\section{Siglinda (Con temor)}

¡Oh, silencio!... Alguien sale... Mira... ¿Has oído?

Sigmundo (Atrayéndola con violenta ternura)

No temas, no... bien mío... Nadie ha salido.

Es alguien que nos llama, que nos espera...

Es la vida que ríe... la Primavera...

Huye el invierno y, mientras, surge enseguida

la hermosa Primavera, llena de vida...

Flota en las tibias brisas, y en la espesura, suave y voluptuosa, vibra y murmura; suspira entre los bosques y se recrea, las flores de los campos mece y orea; de amor sus grandes ojos son las prisiones, los trinos de las aves son sus canciones, es su aliento de perfume que dan las rosas, su savia las mantiene frescas y hermosas; sin más armas que un beso, la tierra entera encadenó a sus plantas la Primavera... $\mathrm{Al}$ vigoroso asalto que dio cedieron los muros, y esas puertas, rotas, cayeron para que entrar pudiera, gentil y ufana, la Primavera hermosa, de Amor hermana... De Amor, por quien el pecho sufre y delira, de Amor, que en nuestras almas canta y suspira. ¡Amor somos nosotros! La Primavera con sus leyes nos salva por vez primera, y al romper la muralla que nos cubría llena tierras y cielos con su alegría...

La dicha a nuestras almas ha descendido... ¡Amor y Primavera se han reunido! ${ }^{51}$

\footnotetext{
${ }^{50}$ WAgner, R. La Valquiria. Libreto..., pp. 77-79.

${ }^{51}$ «Teatros y autores. Real». El Mundo Naval Ilustrado, III, 43 (1 de febrero de 1899), p. 58.
} 
Siguiendo la estructura del texto, se comentan seguidamente algunos aspectos que nos parece oportuno aclarar. La traducción castellana del Canto de la primavera fue muy conocida en la época y, creemos, fácilmente reconocible por los lectores, puesto que había sido reproducida con anterioridad en un libro de Rodrigo Soriano ${ }^{52}$ y en varios periódicos madrileños ${ }^{53}$, entre otros la famosa revista La Ilustración Española y Americana ${ }^{54}$. Su popularidad hizo posible la introducción del elemento paródico, en este caso sustituyendo el poema original de Cadenas y París por estrofas de seguidilla arromanzadas, con su típica alternancia de heptasílabos y pentasílabos con rima asonante en los versos pares, que dan al texto gran frescura, dotándolo de regusto popular y humorístico. Por cierto, la versión rítmica usada en las representaciones del Teatro Real -atribuidas durante algún tiempo a Luis París en exclusiva- fueron objeto de la burla de Gedeón, en un grabado anterior en el que parecen tener doble sentido tanto la imagen como el texto adjunto: «La Walkiria en castellano de París $»^{55}$. En el dibujo se ve a una valquiria sobre un caballo desbocado ante los atropellos cometidos al diccionario español, pero tanto su desnudez como su negra cabellera no concuerdan con el modelo iconográfico de las deidades recogidas por Wagner de la mitología nórdica (en tanto que guerreras van con cota de malla), sino más bien con la personificación de Cuba, una mujer indígena antillana que fue publicada en el propio Gedeón en varias ocasiones. Resulta elocuente, creemos, que la frase entrecomillada se publicara tan solo unas horas antes de que dieran comienzo las negociaciones del tratado de paz en la ciudad de París, así que la que parece se pierde despavorida - y definitivamente- es la isla caribeña (Ilustración 5).

Volviendo al canto de amor de Camelundo, tras aclarar que Sagasta aún no se ha marchado del gobierno, el texto menciona, de manera un tanto enigmática para el lector actual, a un personaje que aguarda a los contrayentes del matrimonio político en los alrededores del Palacio Real. Pero lo hace oculto, agazapado, en la sombra, aunque esta espera furtiva

\footnotetext{
${ }^{52}$ Soriano, Rodrigo. La Walkyria en Bayreuth. Viaje a la Meca del Wagnerismo: La tetralogía (con varios grabados e ilustraciones). Madrid, Tip. Herres a cargo de José Quesada, 1898, Apéndice VII, pp. XXXIII-XXXVII.

${ }^{53}$ Entre ellos El Correo, que lo publicó en primera página el 21 de enero.

${ }^{54}$ «La Walkyria (adaptación al castellano, de los Sres. París y Cadenas). Acto Primero. Escena tercera. Sieglinda y Segismundo». La Ilustración Española y Americana, XLIII, 111 (22 de enero de 1899), pp. 46-47.

${ }^{55}$ «La temporada próxima». Gedeón, IV, 151 (29 de septiembre de 1898), p. 4.
} 


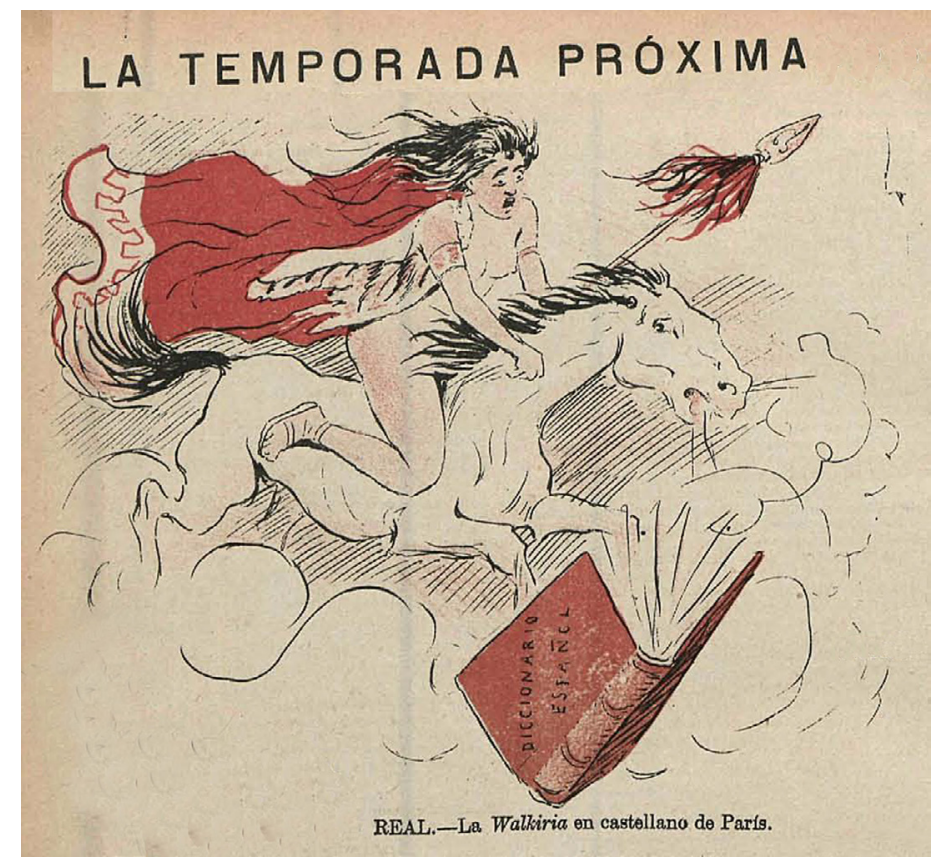

Ilustración 5. «La temporada próxima», Gedeón. Sileno, 1898.

es plácida y cómoda para él, tal y como refleja la cita de Marina, de Emilio Arrieta, sobre el balanceo del agua (acto III, número 19). En este pasaje Camelundo está hablando del cardenal Antonio María Cascajares (1834-1901), miembro del Consejo de Regencia de María Cristina de Habsburgo-Lorena, que fue considerado el principal intermediario en la unión entre Silvela y Polavieja ${ }^{56}$. Los puntos de coincidencia entre Cascajares y Polavieja son múltiples. La obsesión del religioso era regenerar el país a través de la fundación de un gran partido nacional constituido por la unión de todos los católicos. Esta formación — que no llegó a establecerse- debía proteger los intereses de las órdenes regulares en las colonias, especialmente de los jesuitas, puesto que eran — dice Cascajares - «verdaderos baluartes de la soberanía de España en Filipinas» ${ }^{57}$. Por su parte, Polavieja había logrado dominar la insurrección en este archipiélago con distintas victorias que, ensalzadas y orquestadas convenientemente por la prensa, consiguieron

\footnotetext{
56 «Sección telegráfica y telefónica. La crisis. Cascajares». Las Noticias, IV, n 1032 (17 de enero de 1899), p. 4.

${ }^{57}$ Cascajares, Antonio María. En justa defensa. Valladolid, Imp. y Lib. Católica de José Manuel de la Cuesta, 1898, p. 4.
} 
afianzar su imagen de héroe y salvador de la patria. Por eso, a su regreso a España se pusieron en él todo tipo de esperanzas militares y políticas, de manera que Cascajares vio en Polavieja a la persona enérgica que podía acometer las reformas, el ansiado "cirujano de hierro», que diría Joaquín Costa ${ }^{58}$. El mantenimiento del Concordato con la Santa Sede y la defensa de los intereses de los jesuitas presuponían un fuerte desembolso de dinero para el Estado, de ahí que en una de las estrofas leamos que el misterioso personaje que viste de cura «se queda con los cuartos».

Tras la velada alusión a Cascajares, el poema que acompaña al grabado de Sileno prosigue presentado a Raimundo Fernández Villaverde como el ariete que usarán Silvela y Polavieja para embestir contra los políticos liberales, pues Villaverde había adquirido fama de ser excesivamente vehemente en un debate sobre los presupuestos celebrado meses atrás, en el cual se opuso acaloradamente a Romero Robledo ${ }^{59}$; tanto es así que Gedeón apostillaba con gracia: «quisiera ser Villaverde, para sacarte a fuerza de puños» ${ }^{60}$. Frente a la alianza conservadora de Silvela y Polavieja se situó, en ese preciso instante, la llamada «concentración liberal», que reunía a Sagasta, Weyler y Romero Robledo. El texto deja entrever que el odio a este último fue un elemento aglutinante de la reacción conservadora, pues Polavieja había dimitido dos años antes como Capitán General de Cuba debido a sus desavenencias con el entonces ministro de Ultramar, Romero Robledo ${ }^{61}$, del cual ya se ha mencionado, por otra parte, su fallida lucha con Silvela para hacerse con el liderazgo del Partido Conservador tras la muerte de Cánovas.

Ambas coaliciones, liberal y conservadora, tuvieron como objetivo último lograr la mayoría necesaria para, respectivamente, poder sacar adelante - o bloquear - los presupuestos del Estado. Acorde a su línea editorial, en el mismo número Gedeón publicó otro grabado que representa a la coalición liberal como una inmensa bola de excrementos que, tratando de ser introducida en el Congreso, es empujada por tres escarabajos peloteros, cuyas cabezas son las de Sagasta, Weyler y Romero Robledo. El dibujo, de Moya, viene acompañado de la siguiente leyenda: «Ya habrán ustedes olido los elementos de que se compone esta bolita regeneradora» ${ }^{62}$. De

\footnotetext{
${ }^{58}$ Morillas Gómez, Javier. «Antonio M $\mathrm{M}^{\mathrm{a}}$ Cascajares. Notas para un centenario». Aportes, 43 (2000), pp. 41-48.

59 «Cabos sueltos». El Siglo Futuro, XXIV, n 7011 (8 de junio de 1898), p. 1.

60 «Jueves de Gedeón». Gedeón, V, 165 (18 de enero de 1899), p. 2.

${ }^{61}$ López Serrano, A. El general Polavieja..., vol. 1, pp. 250-252.

${ }^{62}$ Moya, Joaquín. «La concentración liberal». Gedeón, V, 166 (25 de enero de 1899), p. 4.
} 
ahí la mención, en el poema de Camelundo, a la conocidísima adivinanza popular alusiva a la flatulencia, «entre dos peñas feroces...», recogida por Quevedo en sus Gracias y desgracias del ojo del culo. También la evocación a Joseph Pujol (1857-1945), Le Pétomane, que era extraordinariamente famoso por sus habilidades aerofágicas, a través de las cuales era capaz de reproducir conocidas melodías o imitar a diferentes animales ${ }^{63}$. El peptómano acababa de actuar en Madrid, con gran éxito pero con polémica, porque un periódico juzgó su espectáculo como una frivolidad completamente inapropiada a las circunstancias por las que atravesaba España ${ }^{64}$. Debido a su popularidad, el término fue incorporado en una sección de la revista titulada «Nuevo Diccionario de la Real Academia Gedeónica», en el que se definía al peptómano como: «Hombre habilidoso que es pura envidia de nuestros más geniales y ocurrentes autores cómicos. - Artista que se ha metido la habilidad donde nuestros oradores debían meterse la lengua» ${ }^{65}$. Por otra parte, la bola de excrementos mencionada - o bien una saca con el dinero de los presupuestos - es la que parece llevar Gedeón en la parte superior de la portada reproducida en la Ilustración 4, identificada con la leyenda «concentración liberal». El protagonista de la revista satírica, ataviado como una valquiria, está subido en un caballito con ruedas que, tirado por el perro de otro de los personajes de la publicación, su sobrino Calínez, se desplaza por unos raíles. Formalmente Sileno alude al método con que se puso en escena la cabalgata de las valquirias en el Teatro Real, que usó un sofisticado sistema, semejante a una irregular montaña rusa (Ilustración 6) ${ }^{66}$.

En su trasfondo, la imagen de Gedeón disfrazado como valquiria critica duramente la complacencia, incluso hasta el cierto grado de indolencia, con que la clase política afrontó los primeros momentos del Desastre del 98. El sistema de la Restauración y el turnismo político habían generado una inercia que era compleja de romper porque el poder estaba cómodo y a gusto con la situación sancionada por el Pacto del Pardo. Por eso, había reticencias «a meterse en novedades, y todos» — dice el magazi-

${ }^{63}$ Canals, Salvador. «París. Mi estafeta. Crónica mal oliente». El Heraldo de Madrid, III, n ${ }^{\circ}$ 570 (25 de mayo de 1892), p. 1.

${ }^{64}$ «Llegó...». Heraldo de Madrid, IX, no 2948 (6 de diciembre de 1898), p. 2.

${ }^{65}$ Torres Martínez, José Carlos de. «El semanario satírico Calínez (1899) y su contexto». Filología y Lingüística: estudios ofrecidos a Antonio Quilis. 2 vols., Madrid, CSIC, UNED, Universidad de Valladolid, 2005, vol. 2, p. 2164.

${ }^{66}$ Véase SuÁrez García, José Ignacio. «La puesta en escena de los estrenos wagnerianos en Madrid». Staging Verdi and Wagner. Naomi Matsumoto (ed.). Turnhout, Brepols, 2015, pp. 203-231. 


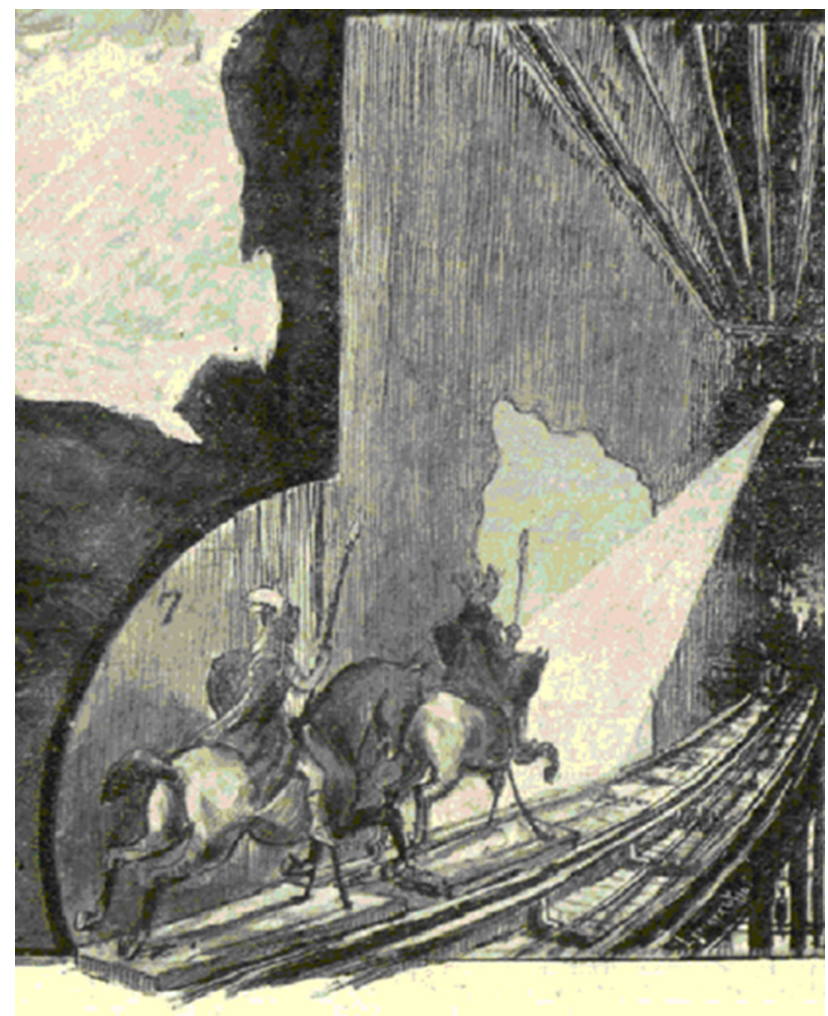

Ilustración 6. Cabalgata de las valquirias en el T. Real, La Ilustración Española y Americana. Comba, 1899.

ne- «vamos a gusto en el machito, es decir, [...] en el caballo blanco de la Valquiria» ${ }^{67}$. El planteamiento trasnochado y romántico con que se afrontaron las guerras coloniales y todos aquellos valores que tanto se habían predicado en España, como el honor, la dignidad, la honradez, la fama, la honra, el derecho internacional, etc., se revelaron como completamente ineficaces. La clase política, sin embargo, siguió anclada en ellos y no afrontó los problemas más acuciantes, como la repatriación de los prisioneros retenidos en Filipinas. Incluso aquellos que pensaban en la regeneración -dice Gedeón en alusión al consorcio entre Polavieja y Silvela - «la ven en forma romántica, en forma de regionalismo o separatismo medieval ${ }^{68}$. En este aspecto, Sileno se nos presenta a lo largo

${ }^{67}$ «Cyranos, Tenorios y Quijotes». Gedeón, V, 166 (25 de enero de 1899), p. 3.

${ }^{68}$ Ibid. 
del conflicto bélico como un caricaturista mucho más realista y menos patriotero que otros coetáneos, como Eduardo Sáenz de Hermúa, que con una ceguera absoluta de las verdaderas circunstancias exaltó a la «madre patria» como una gran potencia capaz de aplastar a Estados Unidos ${ }^{69}$.

\section{Conclusiones}

La capacidad de condensación y resumen de la caricatura la hacen idónea para transmitir contenidos que para el humorista sería muy prolijo describir literariamente, como lo ha sido, de hecho, para nosotros en el presente trabajo. Hemos tratado de hacer comprensibles varias sátiras políticas basadas en temática wagneriana. Algunas usan un modelo narrativo que une viñetas con pies a modo de filacteria, pero en un par de casos la crítica tendenciosa se complica con la inclusión de textos extensos, cuyo espesor tropológico es solamente posible de advertir tras un exhaustivo estudio. En la configuración de los ejemplos extraídos de Gedeón, tanto los títulos como los pies literarios son fundamentales a la hora de la plena comprensión del dibujo. En todos ellos la carga cómica implícita de la imagen sale reforzada con la letra que, en ocasiones, es en verso, utilizando además con frecuencia frases hechas, refranes o citas históricas. En estos aspectos detectamos que los grabados explicados siguen las características generales de la revista en los años que rodean al $98^{70}$. Cuando el artista hace acompañar el dibujo con una letra para hacer comprensible la idea que quiere comunicar, la palabra cobra una función de anclaje, de apoyo clarificador, de revelación incluso de la propuesta figurativa. En el lado contrario está el «humor verbal ilustrado», en el cual el texto es el núcleo significante y la imagen su complemento estético, siendo el grabado sobre Weyler en Blanco y Negro el caso más próximo a este tipo. Entonces el texto se erige en soporte básico, desencadenante de la transgresión y vehículo de la complicidad con el lector-espectador. Lo más habitual, sin embargo, es que imagen y texto se conjuguen de forma complementaria. Por eso podemos calificar al humor gráfico como mensaje «bimedia» porque se da un proceso de comprensión conjunta de palabra e imagen, lo cual ha dificultado sobremanera nuestra exposición, puramente literaria. La

${ }^{69}$ MECACHIS (pseudónimo de SÁenz de Hermúa, Eduardo). «La mejor diplomacia». Blanco y Negro, VI, 255 (21 de marzo de 1896), p. 22.

${ }^{70}$ García Quirós, R. M. «Política y caricatura...», p. 131. 
combinación e interacción de ambos sistemas facilita extraordinariamente la comunicación del chiste al conseguir para el texto una visualización que, de manera inmediata y previa a su lectura, proporciona a los ojos los datos de la escena. Para la imagen consigue una concreción interpretativa por medio de una explicación más precisa de la situación. El resultado de la confluencia de los dos canales es mucho más que la mera suma de texto e imagen, permitiendo variados tipos de sinergias ${ }^{71}$.

En lo concerniente a la parte visual de las sátiras comentadas, podemos afirmar que el estilo es en general realista, detallista, incluso minucioso, si lo comparamos con la profunda transformación que va a sufrir el humor gráfico a comienzos del siglo XX. García Quirós subraya, a este respecto, que los artistas de Gedeón siguen normas establecidas mucho tiempo atrás $y$, en este sentido, su estilo es tradicional, incluso arcaico, pues con el cambio de siglo la caricatura dará un vuelco y renovará su «manera» con obras mucho más simplificadas y esquemáticas ${ }^{72}$. No obstante, aunque en la representación de los políticos en las caricaturas analizadas no hay apenas síntesis formal stricto sensu, el hecho de fijar la semejanza con el modelo a través de los rasgos fisionómicos más resaltables y fácilmente reconocibles (calvas, barbas, gafas, bigotes, etc.) es, en sí mismo, un procedimiento caricaturesco que transforma al personaje en un signo disponible para ser colocado en el más disparatado de los contextos, en cualquier circunstancia o escena por insospechada, patética o ridícula que sea, lo que permite franquear con cierta facilidad las difusas fronteras de lo grotesco. Algo que proporciona esta apariencia burlesca y que, al mismo tiempo, es una forma típica de articulación para hacer llegar el mensaje político, es el recurso del travestimiento, de fácil y rápida comprensión ${ }^{73}$, tal y como se observa en Silvela transformado en Silvelinda. En su idilio de amor con el general Polavieja (Camelundo) se aprecia otro de los temas clásicos de la sátira política, conchabar contra un tercero, porque el fin último de esta coalición fue maniobrar contra Sagasta y echar abajo su propuesta de presupuestos para llegar al gobierno.

El patrón iconográfico del que se sirve el género se basa, muchas veces, en imágenes «cultas» conocidas, que son reaprovechadas con fines cómicos.

\footnotetext{
${ }^{71}$ Álvarez Junco, M. El diseño de lo incorrecto..., pp. 109-110.

${ }^{72}$ García Quirós, R. M. «Política y caricatura...», pp. 130-131.

73 Caparrós Masegosa, Lola y Gamonal Torres, Miguel Ángel. “"Gedeón” en las Exposiciones Nacionales de Bellas Artes (1897-1912). Crítica de arte y caricatura política en la España de la Restauración». Cuadernos de Arte de la Universidad de Granada, 41 (2010), pp. 249267, especialmente pp. 254-256.
} 
Cuando así sucede, se sincretizan en él aspectos relativos a las culturas elevada (imágenes simbólicas y alegóricas) y popular (medios de masas, dichos, etc.), de ahí la mezcla de temas wagnerianos con refranes tradicionales, por ejemplo. De la cultura elevada toma, con frecuencia, modelos emblemáticos que funcionan como marco iconológico, tal y como han revelado Caparrós y Gamonal para el caso de las exposiciones nacionales de Bellas Artes. Este es uno de los motivos por los que historiadores del arte dependientes de la corriente de pensamiento iniciada por Warburg y Panofsky han prestado atención a la sátira política visual ${ }^{74}$ y explica, también, la utilización de temas wagnerianos como moldura icónica. La parodia de la ópera se convierte, así, en una excusa para hacer un retrato deformado de la política de la Restauración, en sí misma grotesca en ocasiones, como se aprecia en la extraña coincidencia — casi estrambótica- de que tanto carlistas como republicanos estuvieran interesados en el general Weyler. Pero lo culto debe responder, además, a la más estricta actualidad para que pueda entrar a formar parte de la prensa y la cultura de masas $\mathrm{y}$, por eso, las representaciones y estrenos wagnerianos se pueden leer en clave política. Por otro lado, la asunción de presupuestos establecidos en el método iconológico de Panofsky no solo resulta útil a la hora de abordar estudios como el presente, sino que puede ayudar a evitar fallos de interpretación, como el producido al identificar erróneamente -en el primer ejemplo tratado (Ilustración 1) - a Weyler llegando a la Gran Antilla para solucionar la insurrección cubana ${ }^{75}$, cuando en realidad se trata, como se ha dicho, de Martínez Campos regresando a España.

En otro orden de cosas, tal y como se dejó apuntado al inicio de nuestra exposición, la etapa finisecular fue especialmente rica en sátira política, porque la óptica jocosa favoreció la evasión ansiada por la sociedad española, impresionada ante la gravedad de los hechos derivados de las guerras coloniales. Por eso se produjo una reacción común a muchas épocas calamitosas, una oleada de risueña despreocupación en los espectáculos, acompañada, en casos como el denominado «género piernográfico $»^{76}$, por una sensualidad alocada. La obra wagneriana, en su conjunto, fue reinterpretada en clave de humor, aunque el asunto predilecto fue Lohengrin.

\footnotetext{
${ }^{74}$ Ibid., pp. 250-255.

${ }^{75}$ Cf. Jiménez Fernández, Lourdes. El reflejo de Wagner en las artes plásticas españolas. De la Restauración a la Primera Guerra Mundial. Tesis doctoral inédita. Universidad de Barcelona, Departamento de Historia del Arte, 2013, pp. 244-245.

${ }^{76}$ Casares Rodicio, Emilio. «Zarzuela». Diccionario de la Zarzuela: España e Hispanoamérica. 2 vols., Emilio Casares Rodicio (dir. y coord.). Madrid, ICCMU, 2006, vol. 2, p. 974.
} 
Lourdes Jiménez ha señalado acertadamente que la figura del Caballero del cisne - como héroe brillante que, sin embargo, finalmente tiene que partir abatido y derrotado sin haber completado del todo su misión, por tener que abandonar a Elsa de Brabante- fue equiparado al triste destino con que se enfrentaron los soldados españoles que se marcharon a luchar a Cuba y Filipinas para defender el honor de Elsa-España, los cuales regresaron derrotados o heridos, en el mejor de los casos ${ }^{77}$. José de Roure comparó explícitamente a aquellos hombres con «pobres Lohengrines», en un artículo dedicado a una representación de Lohengrin en el Teatro Real bajo la dirección de Luigi Mancinelli. El texto, que rezuma pesimismo, tristeza y melancolía, nos sirve a nosotros para subrayar que la aparición de las caricaturas comentadas es, de la misma manera, una manifestación más de aquella actitud que trata de despreocuparse y distraerse a toda costa ante la terrible realidad:

Madrid quiere olvidar, amigo mío. Quiere olvidar que en lejanas tierras se derrama sangre española, y daría los monumentos más preciados de su grandeza [...] porque se borrara de nuestra bandera la franja roja, que crece y crece [...]. Pero no pensemos en cosas tristes; olvidémoslas, como Madrid pretende olvidarlas. ¿Qué cómo las olvida? Con el rumor que producen las puertas de los teatros al abrirse [...]. Como antes te dije, Madrid quiere olvidar. Quiere olvidar que mientras en la escena del regio coliseo aparece Lohengrin cubierto con brillante armadura a proclamar la inocencia de Elsa y a recibir su amor ante una corte de Elsas, menos inocentes, tal vez, pero no peor alhajadas, que se apiñan en los palcos, suena en la Cuesta de San Vicente el ruido del coche de la Cruz Roja que conduce a hospederías y sanatorios a esos pobres Lohengrines de rayadillo, desembarcados en Santander o la Coruña con tanta fiebre como amor patrio. ¡Si sus ojos vieran la sala del Real! Ya sabes: en ciertas familias el temor de una catástrofe aumenta la sed de diversiones. Sería un precioso estudio psicológico, filosófico, social, como quieras llamarlo, el de aquellos individuos que ante las amenazas de probable ruina o bajo el peso de próxima desgracia, se entregan desesperadamente a los excesos del placer, pretendiendo agotar éste para encontrarse insensibles al esperado dolor, como el que se prepara con una borrachera a una puñalada.... Pero no volvamos a las cosas tristes, que tantos y tan bien califican de cursis, amigo mío. Madrid olvida todo lo que puede olvidarse, a fuerza de música ${ }^{78}$.

Un último aspecto queremos abordar antes de concluir, el referido a la popularidad de Wagner en Madrid, condición sin la cual un asunto no puede ser tratado por la caricatura porque, como se ha señalado, sin un

\footnotetext{
77 Jiménez Fernández, L. El reflejo de Wagner..., pp. 244-245.

${ }^{78}$ Roure, José de. «Cartas Madrileñas». Blanco y Negro, VII, 131 (13 de noviembre de 1897), pp. 9-10.
} 
fácil e inmediato reconocimiento por parte del lector-espectador, el humor gráfico no lograría su primera finalidad: hacer reír. Algunos investigadores de la recepción del compositor alemán en Madrid han minusvalorado la importancia del siglo XIX, sobredimensionado, quizás, el peso de los primeros años del siglo XX en este proceso, especialmente hasta $1914^{79}$. Sin embargo, es pertinente recordar que fue precisamente en el arranque del siglo XX donde el fenómeno sufrió un brusco parón, debido a la conservadora gestión del Teatro Real bajo la empresa de José Arana Elorza (1902/03-1906/07), siempre aconsejado por su inseparable asesor artístico, Luis Carmena y Millán. Es más, hasta ese momento, Madrid y Barcelona habían ido más o menos a la par, incluso se podría hablar - grosso modode un ligero adelanto de la capital del Estado, debido, sobre todo, a la ventaja de contar con una agrupación orquestal estable: la Sociedad de Conciertos. Con ello pretendemos hacer notar que, en nuestra opinión, hay que desterrar de la historiografía la falsa idea de la escasa relevancia del siglo XIX en este tema, ya que desde la publicación de la primera traducción española de un escrito de Wagner en $1855^{80}$, hasta el final de la empresa de Luis París en el Real a comienzos de febrero de 1902, la tendencia es invariablemente ascendente. Repetimos: desde el punto de vista sociológico —que no estrictamente técnico-musical- Wagner era enormemente conocido en Madrid desde mucho tiempo atrás. Prueba irrefutable de lo que decimos son la publicación de caricaturas sobre él en 1876, o que fragmentos de Tannhäuser figuraran en los programas que, por votación popular, confeccionó la Sociedad de Conciertos en 1888, 1889 y 1890, dándose el caso, incluso, de que el alemán fuera el único compositor del que hubo dos obras ${ }^{81}$. Los argumentos al respecto podrían multiplicarse, pero renunciamos a insistir en esta cuestión, remitiendo simplemente al lector a la bibliografía que tenemos publicada. Nuestra última reflexión va dirigida a resaltar que, por diversos motivos, la partitura más en boga fue Lohengrin, cuya fama posibilitó la realización de tres parodias basadas en la ópera ${ }^{82}$. Que Wagner estaba de moda en los años finales del siglo

\footnotetext{
${ }^{79}$ Cf. Ortiz de Urbina Sobrino, Paloma. «Primera recepción de Richard Wagner en Madrid». The Legacy of Richard Wagner. Luca Sala (ed.). Turnhout, Brepols, 2012, pp. 399-415.

${ }^{80}$ WAGNER, Richard. «La música alemana apreciada por Ricardo Wagner». Gaceta Musical de Madrid, I, 19 (10 de junio de 1855), pp. 3-4. Aclaramos que solo se traduce una parte del texto, no enteramente.

${ }^{81}$ SuÁREZ, José Ignacio. «La recepción de la obra de Richard Wagner en Madrid entre 1877 y 1893». Cuadernos de Música Iberoamericana, 14 (2007), pp. 73-142, especialmente pp. 105-107.

${ }^{82}$ SuÁrez García, José Ignacio. «Parodias españolas sobre Lohengrin». Musical Theatre in Europe 1830-1945. Michela Niccolai y Clair Rowden (eds.). Turnhout, Brepols, 2017, pp. 139-176.
} 


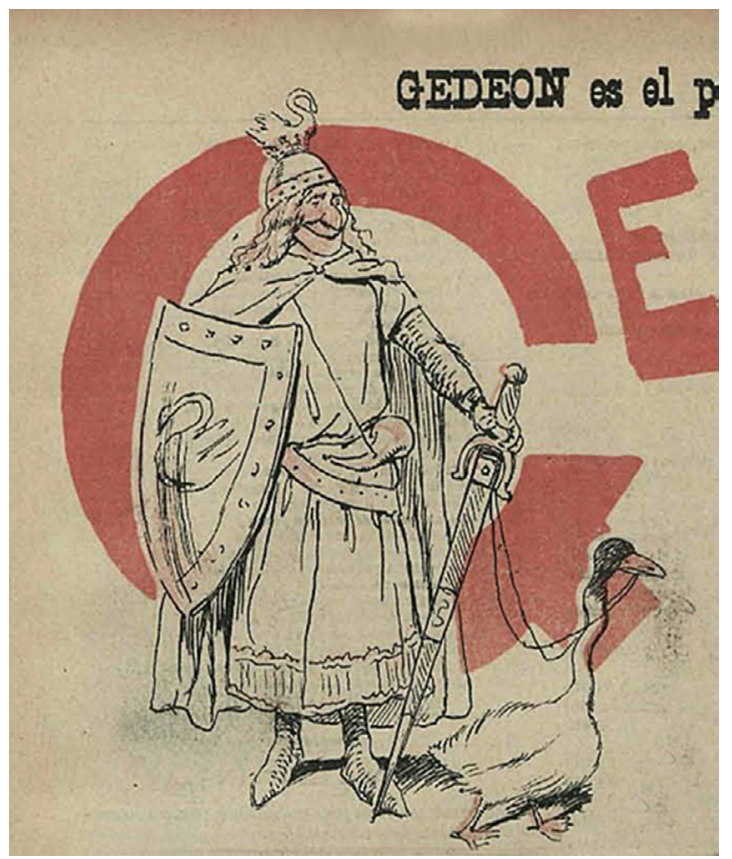

Ilustración 7. Gedeón disfrazado de Lohengrin, Gedeón. Sileno, 1897.

XIX es algo incuestionable, tanto que, hasta el protagonista de la revista satírica más característica de la época, Gedeón, no pudo sustraerse a la tentación de disfrazarse él mismo de Lohengrin en noviembre de 1897, con motivo de la inauguración de la temporada en el Teatro Real (Ilustración 7): sirva esta imagen de colofón al presente artículo.

Recibido: 18 julio 2017 Aceptado: 14 enero 2018 